\title{
Jak skutecznie leczyć wysiękową postać zwyrodnienia plamki związanego z wiekiem według schematu PRN? Rola biomarkerów widocznych w obrazach optycznej koherentnej tomografii
}

\section{How to effectively treat the exudative form of age-related macular degeneration according to PRN regimen? The role of biomarkers detectable in optical coherence tomography}

\author{
Anna Matysik-Woźniak ${ }^{1}$, Marek Rękas ${ }^{2}$,Emilia Bielecka ${ }^{1}$, Robert Rejdak ${ }^{1}$ \\ ${ }^{1} K$ Klinika Okulistyki Ogólnej, Uniwersytet Medyczny w Lublinie, Polska \\ ${ }^{2}$ Klinika Okulistyki, Wojskowy Instytut Medyczny w Warszawie, Polska
}

\section{STRESZCZENIE}

Optymalizacja leczenia uwzględniająca indywidualny przebieg choroby nadal pozostaje jednym z podstawowych problemów w leczeniu wysiękowej postaci zwyrodnienia plamki związanego z wiekiem (AMD). W niniejszej pracy autorzy zawarli wskazówki, które mogą być pomocne podczas terapii według schematu pro-re-nata (PRN). Obecnie ma on zastosowanie u większości pacjentów będących w programie lekowym. Jednym z podstawowych problemów jest właściwa ocena aktywności choroby, która stanowi podstawę decyzji o wykonaniu kolejnej iniekcji leków blokujących czynnik wzrostu śródbłonka naczyń (anty-VEGF). Określenie parametrów, takich jak stan fotoreceptorów czy nabłonka barwnikowego siatkówki (RPE), lokalizacja płynu, zachowanie prawidłowego układu warstw siatkówki, obecność schorzeń pogranicza szklistkowo-siatkówkowego, wpływa na ocenę stanu klinicznego i rokowanie chorych.

SŁOWA KLUCZOWE: zwyrodnienie plamki związane z wiekiem; aflibercept; ranibizumab; schemat PRN; biomarkery; optyczna koherentna tomografia

Ophthalmol J 2018; Vol. 3, No. 2, 47-57

\section{ABSTRACT}

Optimisation of a treatment which takes into consideration the individual course of a disease remains an essential issue in the treatment of the exudative form of AMD. The authors of this study offer guidance, which may facilitate the use of pro-re-nata (PRN) regimen, which is employed for most patients covered by therapeutic program. One of the basic problems still concerns a proper assessment of disease activity, which is crucial for administration of another anti-VEGF injection. Such parameters as, for example, the state of photoreceptors, retinal pigment epithelium (RPE), location of the fluid, the maintenance of the normal organisation of retinal layers, are all relevant to clinical condition and prognosis.

KEY WORDS: age related macular degeneration; aflibercept; ranibizumab; PRN regimen; biomarkers; OCT

Ophthalmol J 2018; Vol. 3, No. 2, 47-57 


\section{WSTĘP}

Iniekcje doszklistkowe leków blokujących czynnik wzrostu śródbłonka naczyń (anty-VEGF, anti-vascular endothelial growth factor) stanowią terapię $\mathrm{z}$ wyboru wysiękowej postaci zwyrodnienia plamki związanego $\mathrm{z}$ wiekiem (AMD, age-related macular degeneration). Niestety, jest to postępowanie objawowe, niezapewniające trwałego wyleczenia, które ma na celu uzyskanie poprawy lub utrzymanie możliwie najlepszej ostrości wzroku w jak najdłuższej perspektywie. Terapia rozpoczyna się od potwierdzenia obecności aktywnej błony neowaskularnej i jest procesem rozciągniętym w czasie. Iniekcje muszą być powtarzane nierzadko przez wiele lat. Przykładowo, w badaniu SEVEN-UP wykazano, że około 50\% pacjentów wymagało iniekcji w 7. roku leczenia [1]. U wielu osób właściwa terapia pozwala na długotrwałe utrzymanie użytecznej ostrości wzroku lub nawet na poprawę widzenia $[1,2]$. Ma to ogromne znaczenie zwłaszcza dla chorych jednoocznych.

Obecnie (w marcu 2018 ok. 17550 oczu mających status "w toku”) większość pacjentów w programie lekowym ukończyło już pierwszy rok terapii. stąd wynika, że są oni leczeni według schematu PRN (pro-re-nata), w którym o podaniu kolejnej iniekcji decyduje lekarz prowadzący. Schemat PRN w programie lekowym stosuje się od 1. roku leczenia preparatem Lucentis i od 2. roku leczenia preparatem Eylea (tab. 1). Stąd, niezależnie od leku, którym rozpoczyna się terapię $\mathrm{w}$ programie lekowym, pacjent $\mathrm{z}$ dużym prawdopodobieństwem będzie kiedyś leczony schematem PRN.

Schemat PRN uwzględniający indywidualizację leczenia uzależnioną od przebiegu choroby jest bardziej wymagający dla lekarza w porównaniu ze schematami sztywnymi. Zbyt mała liczba iniekcji nie zapewnia dostatecznej kontroli i powoduje progresję choroby. Choć u niektórych pacjentów w trakcie leczenia mogą się pojawić zmiany atroficzne siatkówki [3], to i tak terapia anty-VEGF stanowi podstawę leczenia aktywnej neowaskularyzacji (zobacz też akapit: „Atrofia nabłonka barwnikowego siatkówki”). Innymi słowy: właściwe leczenie to odpowiednia liczba iniekcji podana w stosownym czasie $[4,5]$. Oczywiście takie postępowanie nie należy do łatwych, ponieważ grupa pacjentów jest heterogenna. Przykładowo wymienić można: różny stopień zaawansowania choroby, typ neowaskularyzacji, indywidualną odpowiedź na leczenie (która może się także zmienić w trakcie leczenia — zjawisko tachyfilaksji), a także inne czynniki, takie jak wiek, palenie tytoniu itd. [6]. Dlatego w praktyce warto stosować zasady wynikające $\mathrm{z}$ wielu przeprowadzonych badań klinicznych oraz wnioski płynące z badań real life. Przykłady różnych badań klinicznych dotyczących afliberceptu i ranibizumabu z uwzględnieniem liczby otrzymanych iniekcji i zmian ostrości wzroku przedstawiono w tabelach 2 i 3. Przytoczono je, by czytelnikowi łatwiej było się zorientować, ile iniekcji podaje się w praktyce średnio na rok (w różnych krajach i ośrodkach). Trzeba jednak pamiętać, że w badaniach tych często analizowano różne populacje pacjentów, $\mathrm{z}$ różną wyjściową wartością ostrości wzroku, leczone odmiennymi schematami. Stąd wynikają niejednokrotnie duże różnice w liczbie wykonanych iniekcji i efektach leczenia.

Tabela 1. Obowiązujące w programie lekowym schematy leczenia ranibizumabem i afliberceptem (sierpień 2017)

\begin{tabular}{|c|c|c|}
\hline Lek & Pierwszy rok leczenia & Drugi rok i kolejne lata leczenia \\
\hline $\begin{array}{l}\text { Ranibizumab } \\
\text { (Lucentis) }\end{array}$ & $\begin{array}{l}1 \text { iniekcja na miesiąc do czasu uzyskania maksymalnej ostrości } \\
\text { wzroku lub braku cech aktywności choroby, tj. braku zmian } \\
\text { w ostrości wzroku oraz innych objawów przedmiotowych } \\
\text { choroby podczas kontynuowania leczenia } \\
\text { Odstępy pomiędzy podaniem kolejnych dawek oraz } \\
\text { częstotliwość wykonywania badań kontrolnych ustala lekarz } \\
\text { prowadzący i powinny być one uzależnione od aktywności } \\
\text { choroby, ocenianej na podstawie ostrości wzroku lub } \\
\text { parametrów anatomicznych (w przypadku gdy odstęp między } \\
\text { podaniem kolejnych dawek został ustalony na więcej niż } \\
2 \text { miesiące, badania kontrolne pacjenta muszą być wykonywane } \\
\text { nie rzadziej niż co } 2 \text { miesiące, tj. nie rzadziej niż co } 62 \text { dni) }\end{array}$ & $\begin{array}{l}\text { Kontynuacja zasad z 1. roku (w przypadku gdy } \\
\text { odstęp między podaniem kolejnych dawek } \\
\text { został ustalony na więcej niż } 2 \text { miesiące, } \\
\text { badania kontrolne pacjenta muszą być } \\
\text { wykonywane nie rzadziej niż co } 2 \text { miesiące, } \\
\text { tj. nie rzadziej niż co } 62 \text { dni) }\end{array}$ \\
\hline $\begin{array}{l}\text { Aflibercept } \\
\text { (Eylea) }\end{array}$ & $\begin{array}{l}1 \text { wstrzyknięcie na miesiąc w } 3 \text { kolejnych dawkach, następnie } \\
1 \text { wstrzyknięcie co } 2 \text { miesiące }\end{array}$ & $\begin{array}{l}\text { Odstęp pomiędzy dawkami można wydłużyć } \\
\text { - kolejne dawki podaje się w przypadku } \\
\text { pogorszenia się parametrów wzrokowych lub } \\
\text { anatomicznych (w przypadku gdy odstęp między } \\
\text { podaniem kolejnych dawek został ustalony na } \\
\text { więcej niż } 2 \text { miesiące, badania kontrolne pacjenta } \\
\text { muszą być wykonywane nie rzadziej } \\
\text { niż co } 2 \text { miesiące, tj. nie rzadziej niż co } 62 \text { dni) }\end{array}$ \\
\hline
\end{tabular}




\begin{tabular}{|c|c|c|c|c|c|c|c|c|}
\hline \multirow[b]{2}{*}{ Nazwa badania/kraj } & \multicolumn{2}{|c|}{ Rok 1, } & \multicolumn{2}{|c|}{ Rok 2, } & \multicolumn{2}{|c|}{ Rok 3, } & \multicolumn{2}{|c|}{ Rok 4, } \\
\hline & $\begin{array}{l}\text { Iniek- } \\
\text { cje }\end{array}$ & $\begin{array}{l}\text { BCVA } \\
\text { (w literach } \\
\text { ETDRS) }\end{array}$ & Iniekcje & $\begin{array}{l}\text { BCVA } \\
\text { (w literach } \\
\text { ETDRS) }\end{array}$ & $\begin{array}{c}\text { Iniek- } \\
\text { cje }\end{array}$ & $\begin{array}{l}\text { BCVA } \\
\text { (w literach } \\
\text { ETDRS) }\end{array}$ & $\begin{array}{l}\text { Iniek- } \\
\text { cje }\end{array}$ & $\begin{array}{l}\text { BCVA } \\
\text { (w literach } \\
\text { ETDRS) }\end{array}$ \\
\hline \multicolumn{9}{|c|}{ Badania real life evidence (RLE) } \\
\hline PERSEUS [7] Niemcy & 5,8 & $\begin{array}{c}+5,5(8,1, \\
\text { jeśli pacjenci } \\
\text { byli leczeni } \\
\text { wg ChPL; } \\
7,5 \text { iniekcji) }\end{array}$ & & & & & & \\
\hline RAINBOW [8] Francja & 6,1 & $+6,7$ & & & & & & \\
\hline $\begin{array}{l}\text { J-PMS (dane z } 6 \text { mies,, } \\
\text { populacja treatment-naive } \\
\text { i pretreated) [9] Japonia }\end{array}$ & 3,5 & $+6,6$ & & & & & & \\
\hline $\begin{array}{l}\text { Karolinska Institutet } \\
(18 \text { mies,) [10] Szwecja }\end{array}$ & 7,7 & $+7,2$ & $\begin{array}{l}\text { 2,2 (średnia } \\
\text { w } 18 \text {. mies.) }\end{array}$ & $\begin{array}{l}+8,7 \text { (średnia } \\
\text { w 18. mies.) }\end{array}$ & & & & \\
\hline $\begin{array}{l}\text { UK AMD/DR EMR Report } \\
\text { IX [11] Wielka Brytania }\end{array}$ & 7 & $+6,1$ & & & & & & \\
\hline $\begin{array}{l}\text { Moorfields Hospital [12] } \\
\text { Wielka Brytania }\end{array}$ & 7,3 & $+5,4$ & 4,2 & $+5,1$ & & & & \\
\hline $\begin{array}{l}\text { Fight Retinal Blindness } \\
\text { [13] Australia }\end{array}$ & 7,8 & BD & 5,7 & +6 & & & & \\
\hline $\begin{array}{l}\text { UKAA }[14,15] \text { Wielka } \\
\text { Brytania }\end{array}$ & 7 & $+5,1$ & 3,7 & $\begin{array}{l}\text { +2,8 (3,8 wśród } \\
\text { osób, które } \\
\text { otrzymały } \\
\text { 4-5 iniekcji) }\end{array}$ & & & & \\
\hline \multicolumn{9}{|c|}{ Badania kliniczne i ich przedłużenia } \\
\hline $\begin{array}{l}\text { VIEW } 1 \text { extension [16] } \\
\text { USA, Kanada }\end{array}$ & 7,6 & $+10,4$ & 3,6 & $+10,2$ & 6,5 & BD & 6,5 & 7,1 \\
\hline $\begin{array}{l}\text { ATLAS b, mała populacja } \\
\text { USA [17] }\end{array}$ & 8 & $+7,2$ & 6,5 & $+2,4$ & & & & \\
\hline
\end{tabular}

W tabeli podano wartości średnie dla liczby wykonanych iniekcji i zmian ostrości wzroku, BCVA (best corrected visual acuity) — najlepiej skorygowana ostrość wzroku; ETDRS — Early Treatment Diabetic Retinopathy Study; BD — brak danych

\begin{tabular}{|c|c|c|c|c|c|c|c|c|}
\hline \multirow[t]{2}{*}{ Badanie } & \multicolumn{2}{|c|}{ Rok 1.} & \multicolumn{2}{|c|}{ Rok 2.} & \multicolumn{2}{|c|}{ Rok 3.} & \multicolumn{2}{|c|}{ Rok 4.} \\
\hline & Iniekcje & $\begin{array}{l}\text { BCVA } \\
\text { (w literach } \\
\text { ETDRS) }\end{array}$ & $\begin{array}{l}\text { Iniek- } \\
\text { cje }\end{array}$ & $\begin{array}{l}\text { BCVA } \\
\text { (w literach } \\
\text { ETDRS) }\end{array}$ & $\begin{array}{l}\text { Iniek- } \\
\text { cje }\end{array}$ & $\begin{array}{l}\text { BCVA } \\
\text { (w literach } \\
\text { ETDRS) }\end{array}$ & $\begin{array}{l}\text { Iniek- } \\
\text { cje }\end{array}$ & $\begin{array}{c}\text { BCVA } \\
\text { (w literach } \\
\text { ETDRS) }\end{array}$ \\
\hline \multicolumn{9}{|c|}{ Badania real life evidence (RLE) } \\
\hline LUMINOUS [18] & $\begin{array}{c}\text { Niemcy: } 4,3 \\
\text { Holandia: } 5,5 \\
\text { Belgia: } 5,7 \\
\text { Szwecja: } 4,7\end{array}$ & $\begin{array}{c}\text { Niemcy: }-0,8 \\
\text { Holandia: }+5,6 \\
\text { Belgia: }+2,5 \\
\text { Szwecja: }+1,0\end{array}$ & & & & & & \\
\hline $\begin{array}{l}\text { COMPASS [19] } \\
\text { Niemcy }\end{array}$ & 4,5 & $<1$ & & & & & & \\
\hline $\begin{array}{l}\text { TERRA [20] } \\
\text { Wielka Brytania }\end{array}$ & 8,9 & $+7,6$ & & & & & & \\
\hline $\begin{array}{l}\text { UK AMD/DR EMR Report } \\
\text { IX [11] Wielka Brytania }\end{array}$ & 5,8 & $+1,6$ & & & & & & \\
\hline Silva Portugalia [21] & 3,8 & $-1,6$ & 1,6 & $-5,1$ & & & & \\
\hline $\begin{array}{l}\text { UK EMR [22] Wielka } \\
\text { Brytania }\end{array}$ & 5,7 & +2 & 3,7 & +1 & 3,7 & -2 & & \\
\hline AURA [5] różne kraje & 5 & $+2,4$ & 2,2 & $+0,6$ & & & & \\
\hline \multicolumn{9}{|c|}{ Badania kliniczne i ich przedłużenia } \\
\hline LUCAS [23] Norwegia & 8 & $+8,2$ & 8 & $+6,6$ & & & & \\
\hline TREX-AMD [24] USA & 10,1 & $+10,5$ & 8,5 & $+8,7$ & & & & \\
\hline Chen et al. [25] & 9,4 & $+8,2$ & 7,8 & $+7,9$ & & & & \\
\hline HARBOR [26] USA & 7,7 & $+8,2$ & 5,6 & $+7,9$ & & & & \\
\hline $\begin{array}{l}\text { PRONTO mała } \\
\text { populacja [27] }\end{array}$ & 5 & $+9,3$ & 5 & $+11,1$ & & & & \\
\hline $\begin{array}{l}\text { HORIZON (1. i } 2 . \text { rok } \\
\text { ANCHOR, MARINA, } \\
\text { FOCUS) [28] USA }\end{array}$ & 12 & +9 & 12 & +9 & 2,1 & $+4,1$ & 4,5 & +2 \\
\hline
\end{tabular}

W tabeli podano wartości średnie dla liczby wykonanych iniekcji i zmian ostrości wzroku. BCVA (best corrected visual acuity) — najlepiej skorygowana ostrość wzroku; ETDRS — Early Treatment Diabetic Retinopathy Study 
Rozpoczęcie leczenia w schemacie PRN zaleca się od częstych (comiesięcznych), regularnych iniekcji doszklistkowych leków anty-VEGF (faza indukcji leczenia), którego celem jest „osuszenie plamki”, oceniane głównie na podstawie optycznej koherentnej tomografii (OCT, optical coherence tomography). Dla większości pacjentów osuszenie plamki przekłada się na pewnego stopnia poprawę widzenia. Stopień ten może być ograniczony przez wiele zmiennych czynników, takich jak wcześniej występująca sucha postać AMD oraz potencjalnie nieodwracalne uszkodzenia RPE i neurosensorycznej części siatkówki przez rozwijającą się błonę neowaskularną.

Szczególnie istotne są pierwsze 3 comiesięczne iniekcje [6, 29]. Zapisy zawarte w programie lekowym umożliwiają takie podejście terapeutyczne w przypadku obu preparatów (zarówno Lucentis, jak i Eylea). Praktycznie we wszystkich badaniach klinicznych (dotyczących każdego ze stosowanych leków anty-VEGF) wykazano, że faza indukcji (zwana również loading phase, rozumiana jako pierwsze 3 comiesięczne iniekcje) to zazwyczaj czas, kiedy poprawa ostrości wzroku jest największa. Potem w większości przypadków następuje plateau i trudniej uzyskać dalszą poprawę (wyjątkiem jest grupa tzw. late responders). Celem kontynuowanego leczenia staje się wobec tego jak najdłuższe utrzymanie ostrości wzroku osiągniętej w fazie indukcji. Choć oczywiście najlepsze byłoby całkowite osuszenie plamki, to jednak u części pacjentów mimo intensywnego leczenia nie udaje się zupełnie wyeliminować płynu. Warto jednak wspomnieć, że pewna niewielka jego ilość położona między częścią neurosensoryczną a RPE oraz pod RPE może być tolerowana, bez negatywnego wpływu na ostrość wzroku (patrz też „Płyn podsiatkówkowy”) [2, 30].

U niektórych pacjentów po fazie indukcji konieczne będą kolejne częste iniekcje przez dłuższy czas. U innych liczba iniekcji potrzebnych do kontrolowania choroby będzie mniejsza. Należy liczyć się z tym, że pewnej grupie chorych trzeba będzie podać średnio więcej niż 5-6 iniekcji rocznie (którą to liczbę podają obecnie statystyki badań real life w odniesieniu do preparatu Lucentis) $[4,5,31]$ (tab. 3). W programie lekowym w przypadku rozpoczęcia terapii preparatem Eylea pacjent „wchodzi” w schemat PRN już po otrzymaniu 7 iniekcji podczas 1. roku leczenia. Jednym z podstawowych pytań staje się więc: kiedy u pacjentów leczonych schematem PRN należy wykonać kolejną iniekcję? Odpowiedzi na to pytanie szukano w wielu badaniach klinicznych. Okazało się, że wysoka skuteczność zależy od właściwych kryteriów reiniekcji i odpowiednio częstych wizyt kontrolnych (np. HARBOR, PRONTO). Z kolei przyjęcie nieprawidłowych kryteriów reiniekcji i zbyt rzadkie monitorowanie pacjenta mają negatywne rezultaty. W jednym z najważniejszych badań real life - AURA - za najbardziej istotne dla rokowania oprócz VA i wieku pacjenta na początku terapii uznano liczbę wizyt kontrolnych połączonych z wykonaniem OCT oraz liczbę wykonanych iniekcji $[5,32]$. W tabeli 4 przedstawiono różnice w wynikach leczenia w poszczególnych krajach, na którą wpływ miały nie tylko liczba wykonanych iniekcji, ale też liczba wizyt kontrolnych połączonych w wykonaniem OCT [5]. Dlatego decyzja o potrzebie iniekcji w schemacie PRN powinna być oparta na wnikliwej analizie aktywności procesu chorobowego, której dokonuje się podczas odpowiednio często zaplanowanych wizyt kontrolnych. W programie lekowym można je wyznaczać nie rzadziej niż co 2 miesiące, ale mogą odbywać się częściej, na przykład co miesiąc, jeśli lekarz prowadzący obawia się przeoczenia wzrostu aktywności choroby.

\section{OCENA AKTYWNOŚCI CHOROBY}

Cały czas poszukuje się obiektywnych parametrów pozwalających ocenić aktywność choroby i wskazujących na potrzebę iniekcji. Określa się je nazwą biomarkerów [30]. Według definicji są to markery stanu biologicznego służące do oceny klinicznej, monitorowania i przewidywania stanu zdrowia pojedynczych osób lub populacji.

W ocenie aktywności wysiękowej postaci AMD podczas leczenia zasadnicze znaczenie mają badania: najlepszej skorygowanej ostrości wzroku (BCVA, best correcetd visual acuity) (ale także zgłaszane przez pacjenta objawy, np. metamorfopsje), OCT oraz stereoskopowa ocena dna oka (np. nowe krwotoki) [2]. Należy podkreślić, że badanie jedynie samej ostrości wzroku jest niewystarczające [2].

Zarówno badanie OCT, jak i ostrości wzroku są obowiązkowe podczas monitorowania leczenia w programie lekowym. Należy zwrócić uwagę, że zmiany morfologiczne poprzedzają zazwyczaj pogorszenie widzenia [6]. W razie potrzeby można wykonać angiografię fluoresceinową lub indocyjaninową. Rośnie także rola badania angio-OCT siatkówki. Badanie to może ukazywać zmiany wielkości błony neowaskularnej, na przykład zmniejszenie pod wpływem leczenia lub przeciwnie — zwiększenie na 


\begin{tabular}{|c|c|c|c|c|c|c|c|}
\hline \multirow[b]{2}{*}{$\begin{array}{l}\text { Badanie } \\
\text { AURA }\end{array}$} & \multirow{2}{*}{$\begin{array}{c}\text { Rok } 1 . \\
\text { BCVA } \\
\text { (w literach } \\
\text { ETDRS) }\end{array}$} & \multicolumn{2}{|c|}{ Rok 2.} & \multirow{2}{*}{$\begin{array}{c}\text { Liczba } \\
\text { pacjentów }\end{array}$} & \multirow{2}{*}{$\begin{array}{c}\text { Liczba } \\
\text { badań BCVA/ } \\
\text { /2 lata }\end{array}$} & \multirow{2}{*}{$\begin{array}{c}\text { Liczba } \\
\text { OCT/2 lata }\end{array}$} & \multirow{2}{*}{$\begin{array}{c}\text { Średnia lic- } \\
\text { zba wizyt/2 } \\
\text { lata }\end{array}$} \\
\hline & & $\begin{array}{c}\text { BCVA } \\
\text { (w literach } \\
\text { ETDRS) }\end{array}$ & $\begin{array}{c}\text { Iniekcje/ } \\
\text { /średnia } \\
\text { przez } \\
\text { okres } 2 \text { lat }\end{array}$ & & & & \\
\hline Wszyscy & $+2,4$ & $+0,6$ & 7,2 & 2227 & & & 13 \\
\hline Wielka Brytania & +6 & $+4,1$ & 9 & 410 & 17,8 & 16,6 & 18,4 \\
\hline Holandia & $+3,8$ & $+2,6$ & 8,7 & 350 & 7 & 5,9 & 12,7 \\
\hline Francja & $+0,8$ & $-1,1$ & 6,3 & 398 & 9,2 & 9,1 & 13,4 \\
\hline Niemcy & $+1,1$ & $-0,8$ & 5,6 & 420 & 7,7 & 3,4 & 10,8 \\
\hline Włochy & 0 & $-2,9$ & 5,2 & 365 & 6,5 & 4,9 & 12,7 \\
\hline Irlandia & $+2,3$ & $+3,3$ & 11 & 49 & $\mathrm{BD}$ & $\mathrm{BD}$ & 13,6 \\
\hline Kanada & $+3,2$ & $+1,6$ & 9,9 & 188 & $\mathrm{BD}$ & $\mathrm{BD}$ & 13,8 \\
\hline Wenezuela & $+2,6$ & $+1,4$ & 3,2 & 47 & $\mathrm{BD}$ & $\mathrm{BD}$ & 8,3 \\
\hline
\end{tabular}

W tabeli podano wartości średnie dla liczby wykonanych iniekcji i zmian ostrości wzroku. VA (visual acuity) — ostrość wzroku; OCT (optical coherence tomography) — optyczna koherentna tomografia; BCVA (best corrected visual acuity) — najlepiej skorygowana ostrość wzroku; ETDRS — Early Treatment Diabetic Retinopathy Study; BD — brak danych

skutek reaktywacji choroby. Ponadto pewne cechy morfologiczne błony, takie jak kształt tworzących ją naczyń, mogą świadczyć o aktywności procesu chorobowego [33].

\section{ROLA BADANIA OCT W SCHEMACIE PRN}

Badanie OCT dostarcza wielu niezwykle cennych informacji na temat stanu siatkówki i rokowania. Początkowo przywiązywano dużą uwagę do pomiarów centralnej grubości siatkówki (CRT, central retinal thickness), rozumianej jako okrąg siatkówki o średnicy $1 \mathrm{~mm}$, którego środkiem jest centrum dołka. Niestety, okazało się, że parametr ten ma wiele ograniczeń. Przykładowo pomiary grubości mogą się różnić pomiędzy poszczególnymi aparatami. Mogą również wystąpić problemy z właściwą segmentacją i powtarzalnością wyników. Za błędne pomiary może odpowiadać zła fiksacja pacjentów [30]. Przyjmuje się, że wzrost grubości siatkówki (mierzony na tym samym aparacie) świadczy o aktywności choroby. Czasem jednak aktywność może być wyrażona jedynie poprzez zmiany morfologiczne, których obecność poprzedza wzrost grubości siatkówki i pogorszenie ostrości wzroku (ryc. 1). Dlatego analiza stanu klinicznego powinna polegać na jednoczesnej ocenie grubości i morfologii siatkówki $[2,30]$. Za najważniejsze i najwcześniejsze objawy reaktywacji neowaskularyzacji podsiatkówkowej (CNV, choroidal neovascularization) i nawrotu choroby w OCT należy uznać pojawienie się w uprzednio „wysuszonej” plamce płynu śródi podsiatkówowego [2, 30, 34-36].

Warto także zwracać uwagę na objawy świadczące o nieodwracalnym uszkodzeniu siatkówki. Czasem obraz OCT świadczy o tak dużym jej uszkodzeniu, że leczenie staje się bezcelowe. Warto tu przywołać zalecenia Royal College of Ophthalmologists: „przed rozpoczęciem leczenia nie powinno być żadnego istotnego, trwałego uszkodzenia struktury dołka. Istotne uszkodzenie struktury jest zdefiniowane jako obecne od dłuższego czasu zwłóknienie lub atrofia w dołku albo istotna przewlekła tarczowata blizna, która w opinii prowadzącego klinicysty uniemożliwiłaby uzyskanie u pacjenta poprawy czynnościowej (czyli zapobiegłaby dalszej utracie wzroku) [37]. Najistotniejsze biomarkery omawiane w niniejszej pracy przedstawiono na rycinie 1 .

\section{PŁYN ŚRÓDSIATKÓWKOWY W FORMIE "CYST" (NAJWAŻNIEJSZY MARKER)}

Płyn śródsiatkówkowy w obrazowaniu OCT to obszary pogrubiałej siatkówki lub częściej okrągłe lub owalne cystoidalne hiporefleksyjne przestrzenie wypełnione płynem (intraretinal cystoid fluid), położone w siatkówce neurosensorycznej (ryc. 1) [30]. Obecność płynu śródsiatkówkowego jest charakterystyczna dla II i III typu neowaskularyzacji oraz dla późnych, zaawansowanych postaci ukrytej neowaskularyzacji, czyli wiąże się z większymi uszkodzeniami siatkówki [szczególnie w obrębie kompleksu 


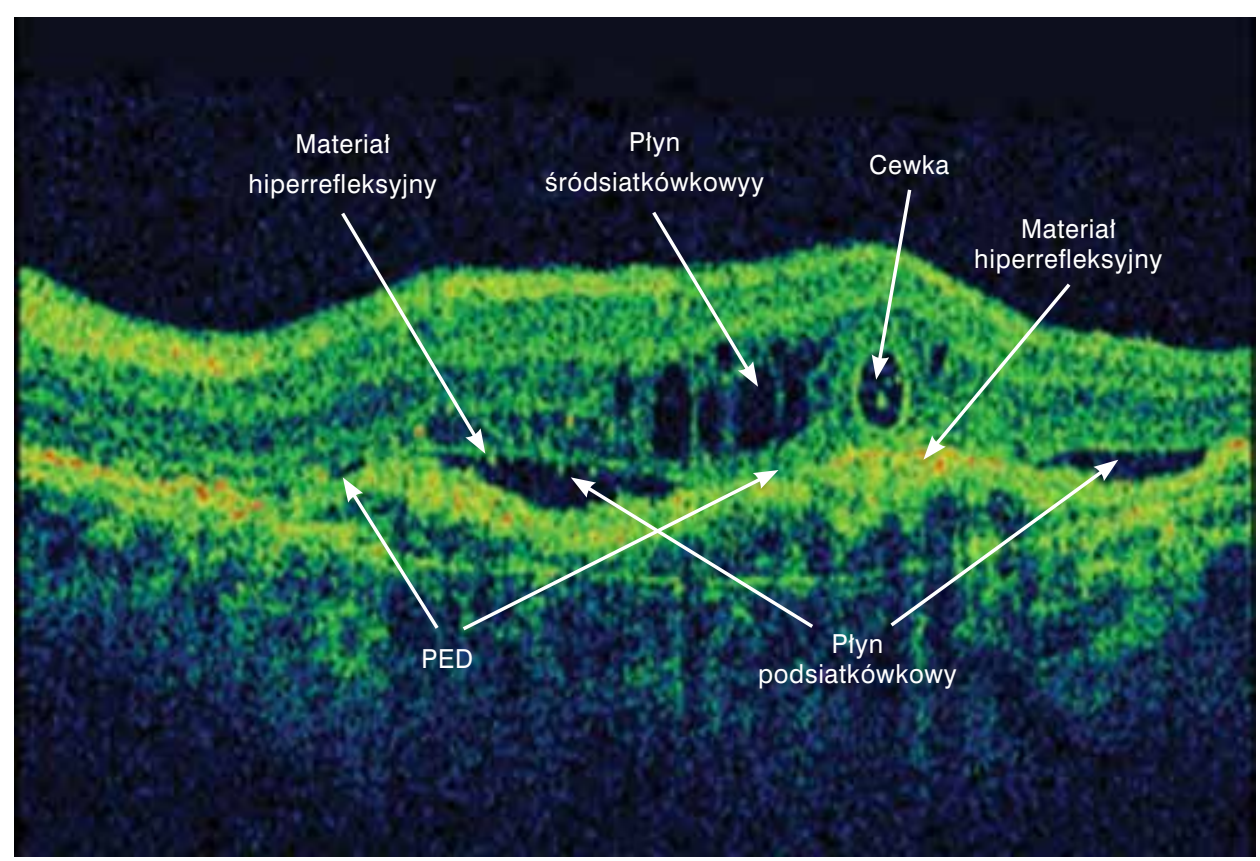

RYCINA 1. Najważniejsze biomarkery w obrazach optycznej koherentnej tomografii

błony granicznej zewnętrznej (ELM, external limiting membrane) i fotoreceptorów]. Często płynowi mogą towarzyszyć: błona neowaskularna (typ II) lub odwarstwienie RPE (typ I, III) [30, 35].

Płyn śródsiatkówkowy to najważniejszy biomarker, który wiąże się z gorszą ostrością wzroku i rokowaniem. Stwierdzono, że źle rokuje obecność płynu śródsiatkówkowego zarówno $\mathrm{w}$ momencie rozpoczęcia terapii, jak i po wykonaniu trzech pierwszych iniekcji $[2,30,35]$. Bardzo istotne znaczenie rokownicze ma także wielkość obszaru siatkówki zajętego przez płyn śródsiatkówkowy i jego lokalizacja względem dołka. Im obszar jest większy i znajduje się bliżej dołka, tym rokowanie gorsze [36]. Sugerowano ponadto, że jeśli dojdzie do dużego obrzęku siatkówki przekraczającego jej limit elastyczności, komórki dwubiegunowe mogą ulec rozerwaniu. Przesyłanie bodźców między fotoreceptorami a komórkami zwojowymi staje się wówczas utrudnione lub niemożliwe. Uszkodzenie komórek dwubiegunowych może być w pewnych przypadkach nieodwracalne, stąd w niektórych oczach mimo ustąpienia obrzęku siatkówki nie dochodzi do poprawy widzenia [38].

W większości przypadków płyn śródsiatkówkowy szybko resorbuje się w wyniku leczenia iniekcjami anty-VEGF, czemu zazwyczaj towarzyszy poprawa ostrości wzroku. Należy dążyć do jego całkowitego wyeliminowania poprzez podawanie kolejnych iniekcji do czasu „osuszenia” neurosensorycznej siatkówki (zero tolerancji). Stwierdzenie obecności płynu śródsiatkówkowego na początku terapii stanowi wskazanie do proaktywnego leczenia (szczególnie pierwszych trzech comiesięcznych iniekcji) [30]. Ponowne pojawienie się płynu stanowi oczywiście wskazanie do pilnej iniekcji. Ważne jest też, by chorzy, u których stwierdza się jego obecność, jak najszybszej otrzymali leczenie. Istotną kwestią pozostaje odróżnienie wysiękowych cyst śródsiatkówkowych od tak zwanych cyst degeneracyjnych, które nie reagują na leczenie anty-VEGF i nie świadczą o aktywnej neowaskularyzacji. Zmiany degeneracyjne to typowo drobne hiporefleksyjne przestrzenie położone nad obszarami uszkodzonego RPE (zaniki lub zbliznowacenia). Przypuszcza się, że zaburzenia RPE prowadzą do zaniku elementów siatkówki neurosensorycznej, a następnie umożliwiają pasywną akumulację płynu surowiczego (jak w gąbce) [30]. W takich przypadkach należy rozważyć, czy dalsze leczenie anty-VEGF jest celowe, ponieważ rokowanie co do poprawy efektów anatomicznych i czynnościowych jest złe [30, 35].

\section{PŁYN PODSIATKÓWKOWY}

Obecność płynu podsiatkówkowego między nabłonkiem barwnikowym a częścią neurosensoryczną (ryc. 1) można stwierdzić we wszystkich typach neowaskularyzacji w przebiegu AMD (najczęściej w typie I). W badaniach klinicznych wykazano, że płyn podsiatkówkowy jest jednym z objawów cho- 
roby, który paradoksalnie nie wiąże się z gorszym rokowaniem. Zaobserwowano, że gdy był obecny na początku terapii, to zarówno ostrość wzroku, jak i odpowiedź na leczenie były lepsze $[2,30,39,40]$. Przebieg choroby był też bardziej stabilny i wymagana była mniejsza liczba iniekcji. Ponadto rzadziej występowały przypadki atrofii geograficznej, nawet jeśli prowadzono intensywne leczenie za pomocą iniekcji anty-VEGF. To „ochronne” działanie płynu niektórzy autorzy tłumaczą obecnością perfuzji CNV, dzięki której fotoreceptory i RPE otrzymują tlen i składniki odżywcze [30]. Warto zwrócić uwagę, że dodatkową korzystną (sprzyjającą łagodnemu przebiegowi choroby) okolicznością towarzyszącą płynowi podsiatkówkowemu jest tylne odłączenie ciała szklistego [30].

Zwykle istotne zmniejszanie się ilości płynu podsiatkówkowego stwierdza się po pierwszych 3 comiesięcznych iniekcjach. Niemniej jednak nie stwierdzono by utrzymywanie się pewnych jego resztkowych ilości miało negatywny wpływ na widzenie [41]. Oczywiście powiększanie się obszaru występowania płynu lub zwiększenia jego ilości podczas wizyt kontrolnych sugeruje wzrost aktywności CNV.

\section{ODWARSTWIENIE NABŁONKA BARWNIKOWEGO}

Odwarstwienie nabłonka barwnikowego (PED, pigment epithelial detachement) bardzo często stwierdza się u pacjentów z wysiękową postacią AMD. Charakterystyczne jest zwłaszcza dla typu I i III neowaskularyzacji. Wyróżnia się następujące typy morfologiczne PED: surowiczy wypełniony optycznie pustym płynem, włóknisto-naczyniowy zawierający niejednorodny hyperrefleksyjny materiał oraz formy mieszane. W wyniku leczenia anty-VEGF czysto surowiczy PED zwykle zupełnie i szybko się cofa. Natomiast znacznie częściej występujący włóknisto -naczyniowy PED zmniejsza się, lecz może pozostawić przewlekłe uniesienia RPE spowodowane obecnością leżących poniżej pozostałości tkanki włóknisto-naczyniowej. Odwarstwienie nabłonka barwnikowego samo w sobie nie wywołuje większych zaburzeń oprócz metamorfopsji [30]. Dopóki neowaskularyzacja jest ograniczona i znajduje się pod RPE, fotoreceptory i część neurosensoryczna siatkówki zachowują swoje funkcje. Duże PED wiąże się z większym ryzykiem przedarcia RPE, zwłaszcza jeśli jego wysokość przekracza $600 \mu \mathrm{m}$, a średnica jest większa niż $5 \mathrm{~mm}$. Do pęknięć spowodowanych terapią anty-VEGF zazwyczaj docho$\mathrm{dzi} w$ trakcie pierwszych trzech iniekcji. Istnieje hipoteza łącząca pęknięcie RPE z obkurczaniem się leżącej poniżej błony neowaskularnej [30]. Warto wspomnieć, że przedarcia RPE same w sobie nie stanowią przeciwskazania do kontynuacji terapii anty-VEGF. Odwarstwienie nabłonka barwnikowego może też pękać samoistnie, u pacjentów jeszcze nieleczonych. Dirani i wsp. stwierdzili pozytywny wpływ trzech pierwszych comiesięcznych iniekcji anty-VEGF na stan anatomiczny i czynnościowy oczu z PED w przebiegu AMD [40].

Jeśli chodzi o podejmowanie decyzji terapeutycznych $\mathrm{w}$ schemacie PRN, to okazało się, że narastanie PED w obszarach związanych $\mathrm{z}$ błoną neowaskularną jest bardzo ważnym czynnikiem ryzyka i wskazaniem do kolejnej iniekcji [2]. Znaczenie tego zjawiska zostało dokładnie opisane przez Schmidt-Erfurth i wsp. (ryc. 2) [30]. Narastanie PED stwierdzane na kolejnych wizytach kontrolnych może świadczyć o utrzymującej się poniżej RPE, przetrwałej neowaskularyzacji. Brak iniekcji w takim momencie (jak wykazano w badaniach klinicznych) prowadzi do dekompensacji i progresji neowaskularyzacji. Efektem tego jest gromadzenie się płynu śród-i podsiatkówkowego. Podanie iniekcji dopiero w tym opóźnionym czasie niestety często nie pozwala na powrót do wcześniejszego stanu anatomicznego i czynnościowego [30]. Ilustrować to może także przypadek pacjenta leczonego w klinice autorów początkowo w ramach jednorodnej grupy pacjentów w procedurze B02. Po otrzymaniu pierwszych trzech comiesięcznych iniekcji uzyskano poprawę ostrości wzorku (do 0,5) i normalizację morfologii siatkówki. Po pewnym czasie zauważono obecność niewielkiego PED okolicy związanej z CNV, jednak nie podano kolejnej iniekcji, ponieważ nie były spełnione obowiązujące wówczas kryteria reiniekcji. Iniekcję wykonano później, gdy doszło do progresji zmian. Niestety, pomimo dalszego leczenia w ramach programu lekowego nie udało się powrócić do stanu, jaki był po pierwszych trzech iniekcjach (ryc. 3). Dlatego podczas kontrolnych OCT powinno się dokładnie obserwować, czy PED się nie zwiększa. W razie stwierdzenia takiego zjawiska konieczne jest natychmiastowe zastosowanie leczenia w celu uniknięcia dalszej progresji zmian.

\section{PODSIATKÓWKOWY MATERIAt HIPERREFLEKSYJNY I BLIZNY}

Podsiatkówkowy materiał hiperrefleksyjny położony między częścią neurosensoryczną a RPE może odpowiadać aktywnej neowaskularyzacji klasycznej lub 


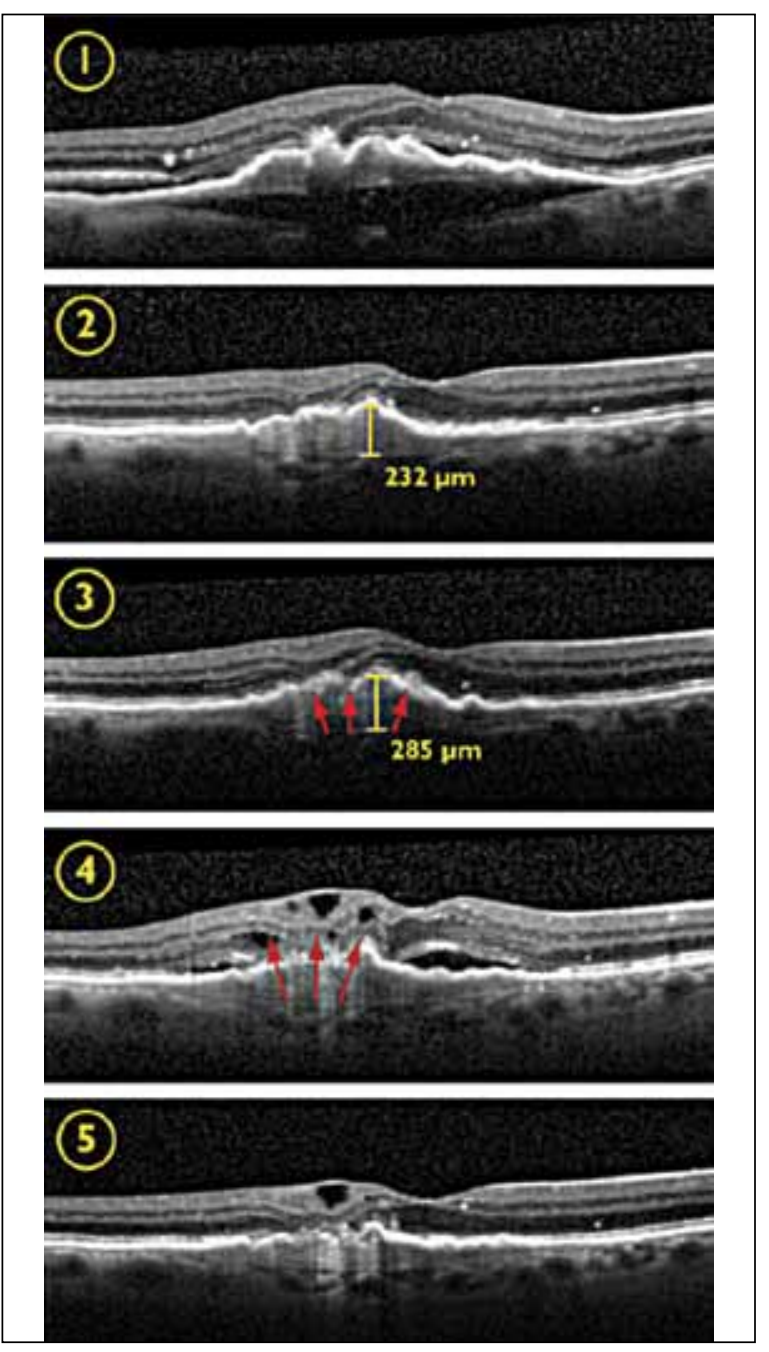

RYCINA 2. Rola narastającego odwarstwienia nabłonka barwnikowego (PED, pigment epithelial detachement) w schemacie leczenia pro-re-nata (PRN) (przedrukowano i przettumaczono za zgodą z [30]). Przykładowy przebieg choroby ilustrujący patogenetyczną koncepcję odwarstwienia nabłonka barwnikowego i wtórnego pojawienia się cyst śródsiatkówkowych jako czynnika ryzyka utraty widzenia podczas leczenia schematem PRN. 1. Początkowy obraz chorego z neowaskularyzacją typu I. Błona neowaskularna widoczna jest jako hiperrefleksyjna tkanka przylegająca do wewnętrznej powierzchni nabłonka barwnikowego. 2. W przebiegu intensywnego leczenia iniekcjami doszklistkowymi osiągnięto wysuszenie siatkówki. Jakkolwiek pozostało uniesienie nabłonka barwnikowego odpowiadające leżącej poniżej tkance włóknistonaczyniowej. Ponieważ stan anatomiczny siatkówki można uznać za satysfakcjonujący, terapię wstrzymano, a pacjent został poddany obserwacji. 3. Widoczny wzrost odwarstwienia nabłonka barwnikowego w trakcie kolejnej wizyty. Odpowiada to wczesnej „cichej” wznowie błony neowaskularnej. Ponieważ pacjent nie wykazywat innych symptomów, większość protokołów terapeutycznych nie zalecało kolejnej iniekcji w tym stanie. 4. Miesiąc później pojawiła się jawna reaktywacja błony neowaskularnej z obecnością płynów śród- i podsiatkówkowego. Wewnątrzsiatkówkowy płyn powoduje uszkodzenie neurosensorycznej siatkówki i pogorszenie widzenia. 5. Pomimo powtarzanej terapii antyangiogennej deficyt funkcjonalny spowodowany nawrotem płynu może się nie cofnąć całkowicie. U tego pacjenta doszło do powstania cyst zwyrodnieniowych położonych nad obszarem atroficznego nabłonka barwnikowego, co widoczne jest jako wzmocnienie transmisji sygnału też jej zwłóknieniu i bliznowaceniu. W tym ostatnim przypadku widoczna jest wyraźnie hiperrefleksyjna struktura, o wyraźnych granicach. Hiperrefleksyjne mogą być także krew oraz wysięki, lecz w tych przypadkach granice nie są ściśle zdefiniowane, a hiperrefleksyjność jest stosunkowo niższa [30]. Obecność hiperrefleksyjnego materiału najczęściej występuje w przypadku neowaskularyzacji typu II i III, natomiast znacznie rzadziej w typie I. Im większy jest obszar i grubość hiperrefleksyjnego materiału oraz im bliżej dołka on się znajduje, tym gorsze jest rokowanie co do ostrości wzroku [2, 42]. Stąd biomarker ten uważany jest za czynnik niekorzystny rokowniczo i występuje często $\mathrm{w}$ grupie non-responders. W przypadku blizn trwale uszkadzających strukturę dołka, dalsze leczenie anty-VEGF może być bezcelowe. Oprócz hiperrefleksyjnego materiału podsiatkówego spotyka się również drobne ogniska hiperrefleksyjne zlokalizowane w siatkówce neurosensorycznej, szczególnie w pobliżu przestrzeni płynowych. Są to prawdopodobnie migrujące komórki RPE, skupiska makrofagów obładowanych barwnikiem, mikrowysięki złożone z lipidów czy włóknika lub aktywowany mikroglej. Przyjmuje się, że ich obecność jest niekorzystna rokowniczo. Świadczą o ryzyku przejścia do bardziej zaawansowanych stadiów choroby i wiążą się z gorszą ostrością wzroku. Ogniska hiperrefleksyjne mogą być także jednym z pierwszych objawów proliferacji naczyń siatkówki (RAP, retinal angiomatous proliferation). W niektórych badaniach ich zanikanie wiązało się z poprawą ostrości wzroku, jednak marker ten nie jest jeszcze szeroko stosowany ze względu na zbyt małą liczbę opracowań na ten temat [30].

\section{ATROFIA NABŁONKA BARWNIKOWEGO SIATKÓWKI}

Atrofia RPE często towarzyszy wysiękowej postaci AMD. Obecność ognisk atrofii RPE zlokalizowanych zwłaszcza w okolicy dołka trwale i w negatywny sposób wpływa na efekty leczenia i ostrość wzroku Najczęściej do atrofii dochodzi w typach neowaskularyzacji II i III. Do innych czynników ryzyka zalicza się: niską ostrość wzroku na początku leczenia $(\leq 20 / 200)$ oraz zanik geograficzny w oku towarzyszącym. Uważa się, że podczas terapii anty-VEGF i zaniku błony neowaskularnej (z wytworzeniem się blizny lub bez obecności blizny) może dojść do atrofii RPE i części neurosensorycznej siatkówki [3, 43-45]. Do chwili obecnej nie ustalono jednak jednoznacznego związku między liczbą wykonanych iniekcji a atrofią RPE. Trwają spekulacje, na ile atrofia 

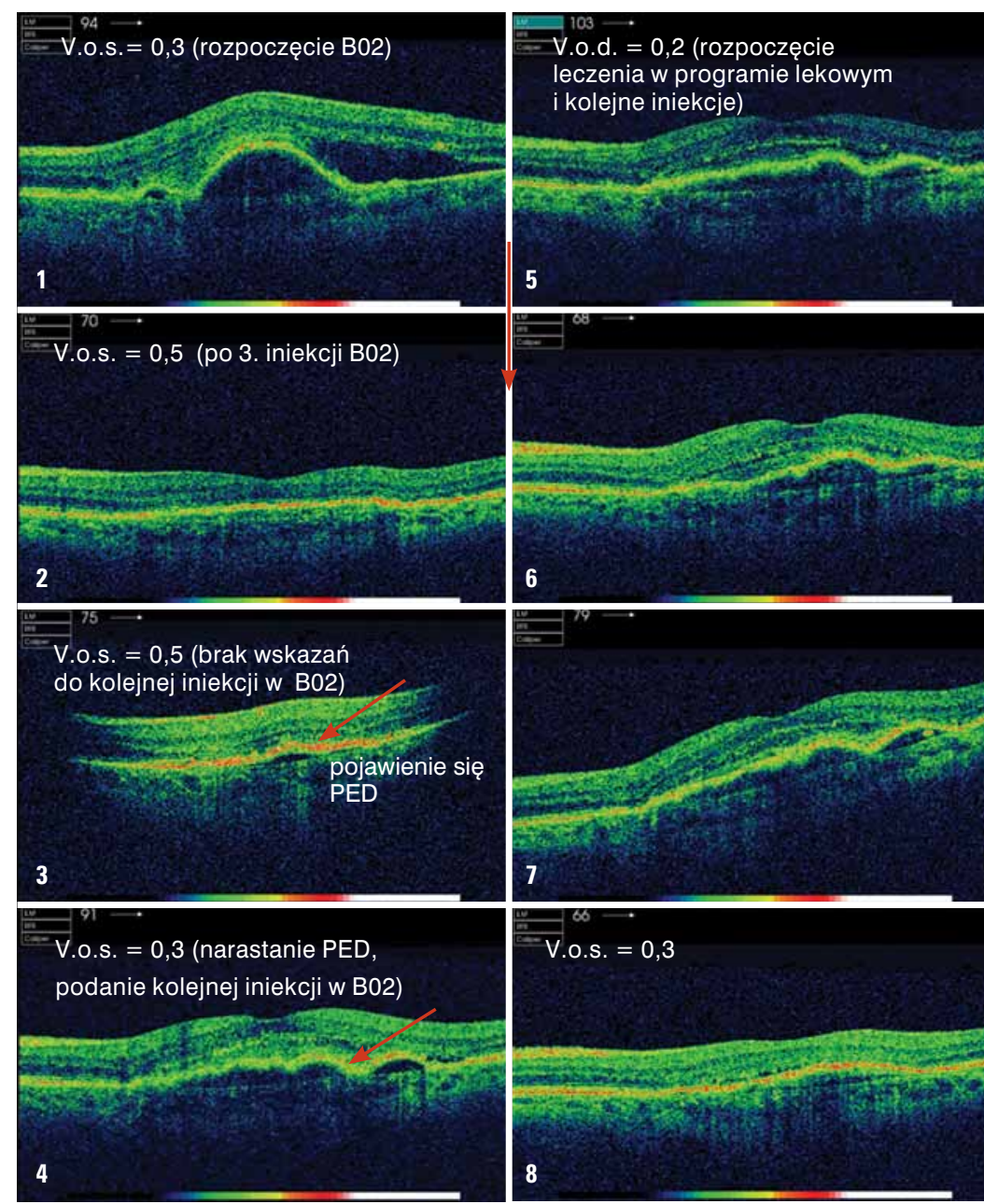
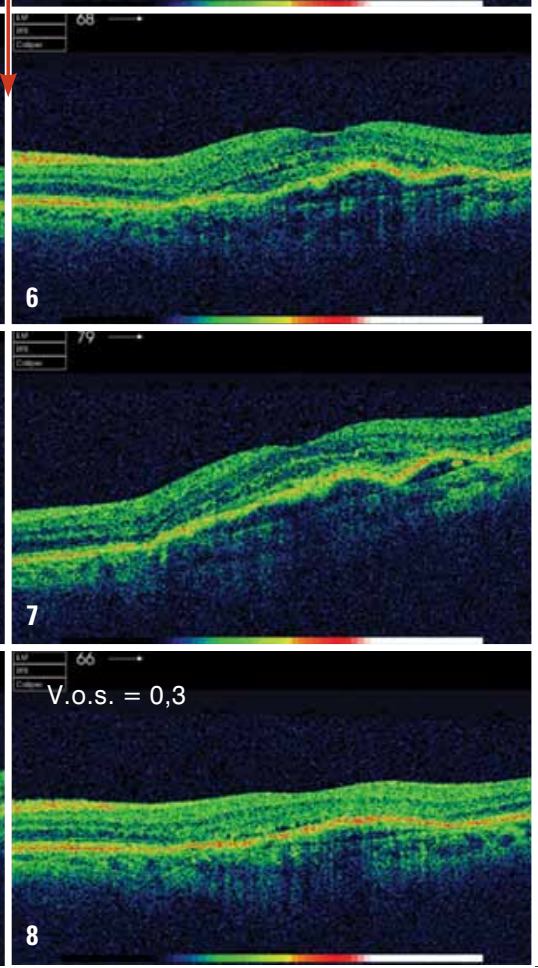
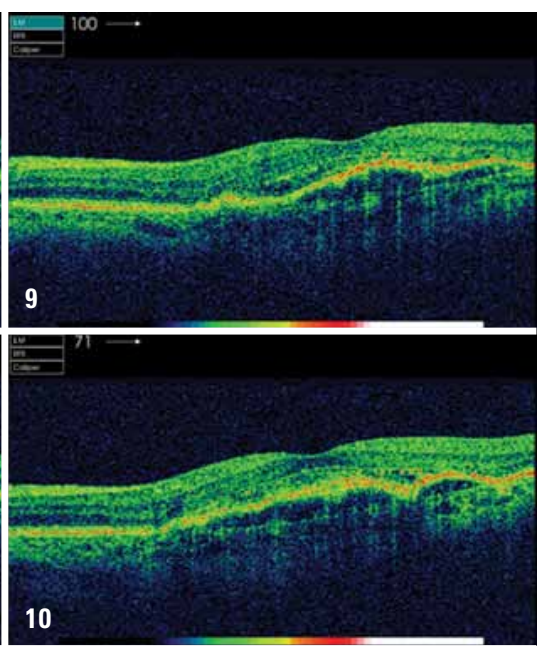

10
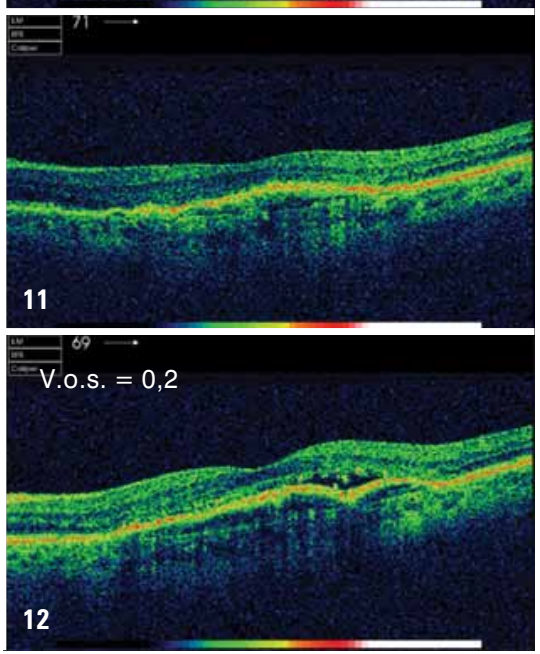

RYCINA 3. Przykład pacjenta leczonego początkowo w ramach jednorodnej grupy pacjentów (JPG) w procedurze B02. Po otrzymaniu pierwszych 3 comiesięcznych iniekcji uzyskano poprawę ostrości wzorku (do 0,5) i normalizację morfologii siatkówki. Podczas kolejnej wizyty kontrolnej zauważono niewielkie uniesienia nabłonka barwnikowego w okolicy odpowiadającej neowaskularyzacji podsiatkówkowej (CNV, choroidal neovascularization). Niestety, kryteria JGP B02 nie pozwalały na podanie iniekcji w tym czasie, ponieważ nie było spełnione kryterium pogorszenia ostrości wzroku o więcej niż jedną linię na tablicy Snellena lub zwiększenie grubości siatkówki o więcej niż $100 \mu$ m. Podanie kolejnej iniekcji w JGP B 02 było możliwe dopiero później, gdy pogorszyła się ostrość wzroku (spadek o 2 linie na tablicy Snellena). Następnie pacjent leczony w programie lekowym. Łącznie otrzymał 14 (w tym 10 iniekcji w Programie Lekowym). Niestety, nie udało się przywrócić ostrości wzroku uzyskanej po trzech pierwszych comiesięcznych iniekcjach (tzw. loading phase). Obecnie podczas regularnych kontroli ostrość wzroku waha się od 0,2-0,3. V.o.d (visus oculi dextri) — ostrość wzroku prawego oka; V.o.s. (visus oculi sinistri) — ostrość wzroku lewego oka

spowodowana jest naturalnym przebiegiem choroby, a w jakim stopniu przyczynia się do niej terapia anty -VEGF. Pojawiały się doniesienia, że u pacjentów stosujących leki w schemacie comiesięcznym ryzyko wystąpienia atrofii było wyższe [46], dlatego niektórzy autorzy sugerują ograniczenie liczby iniekcji do niezbędnej pozwalającej kontrolować chorobę [30].

\section{CEWKI/TUBULACJE W ZEWNEETRZNYCH WARSTWACH SIATKÓWKI}

Zmiany te są uważane za biomarker uszkodzenia fotoreceptorów. Są one położone w warstwie jądrzastej zewnętrznej i widoczne jako hiporefleksyjne, rozgałęzione struktury otoczone hiperrefleksyjnym pierścieniem. Hiperrefleksyjne obrzeże odróżnia cewki od cyst śródsiatkówkowych (płynu śródsiatkówkowego) czy przestrzeni wypełnionych płynem podsiatkówkowym. Ich obecność jest czynnikiem niekorzystnym rokowniczo i świadczy o przewlekłości procesu chorobowego oraz trwałym i nieodwracalnym uszkodzeniu fotoreceptorów. W badaniach histologicznych wykazano, że hiperrefleksyjny pierścień zbudowany jest z ELM i mitochondriów wewnętrznych fragmentów fotoreceptorów. W świetle cewek mogą znajdować się zewnętrzne fragmenty fotoreceptorów i płyn [2]. Zmiany tego typu nie reagują na leczenie. 


\section{BŁONA GRANICZNA ZEWNĘTRZNA I STREFA ELIPSOIDALNA}

Stan błony granicznej zewnętrznej oraz strefy elipsoidalnej [(EZ, elipsoid zone); dawniej określanej jako połączenie między wewnętrznymi a zewnętrznymi fragmentami fotoreceptorów (IS/OS, inner and outer segments)] jest ściśle związany z funkcją widzenia i może być ważnym czynnikiem rokowniczym w podejmowanej terapii anty-VEGF [47]. Struktury te świadczą o integralności fotoreceptorów, a ich zaburzenia wiążą się z gorszym rokowaniem. Praktyka pokazuje jednak, że identyfikacja linii odpowiadających strukturom zewnętrznych warstw siatkówki może być trudna. Być może wprowadzenie nowej generacji aparatów OCT pozwoli na lepszą ocenę tych części siatkówki [30].

$\mathrm{Na}$ zakończenie warto wspomnieć o możliwości cyfrowej obróbki obrazów OCT i inteligentnych systemach samouczących się. Być może w przyszłości komputery będą mogły pomagać lekarzom w podejmowaniu decyzji terapeutycznych [48].

\section{PIŚMIIENNICTWO}

1. Rofagha S, Bhisitkul RB, Boyer DS, et al. SEVEN-UP Study Group. Seven -year outcomes in ranibizumab-treated patients in ANCHOR, MARINA, and HORIZON: a multicenter cohort study (SEVEN-UP). Ophthalmology. 2013; 120(11): 2292-2299, doi: 10.1016/j.ophtha.2013.03.046, indexed in Pubmed: 23642856.

2. Schmidt-Erfurth U, Chong V, Loewenstein A, et al. European Society of Retina Specialists. Guidelines for the management of neovascular age-related macular degeneration by the European Society of Retina Specialists (EURETINA). Br J Ophthalmol. 2014; 98(9): 1144-1167, doi: 10.1136/bjophthalmol-2014-305702, indexed in Pubmed: 25136079.

3. Channa R, Sophie R, Bagheri S, et al. Regression of choroidal neovascularization results in macular atrophy in anti-vascular endothelial growth factor-treated eyes. Am J Ophthalmol. 2015; 159(1): 9-19. e1, doi: 10.1016/j.ajo.2014.09.012, indexed in Pubmed: 25217857.

4. Holz FG, Tadayoni R, Beatty S, et al. Determinants of visual acuity outcomes in eyes with neovascular AMD treated with anti-VEGF agents: an instrumental variable analysis of the AURA study. Eye (Lond). 2016; 30(8): 1063-1071, doi: 10.1038/eye.2016.90, indexed in Pubmed: 27197868.

5. Holz FG, Tadayoni R, Beatty $S$, et al. Multi-country real-life experience of anti-vascular endothelial growth factor therapy for wet age-related macular degeneration. Br J Ophthalmol. 2015; 99(2): 220-226, doi: 10.1136/bjophthalmol-2014-305327, indexed in Pubmed: 25193672.

6. Amoaku WM, Chakravarthy U, Gale R, et al. Defining response to anti-VEGF therapies in neovascular AMD. Eye (Lond). 2015; 29(6): 721-731, doi: 10.1038/eye.2015.48, indexed in Pubmed: 25882328.

7. Framme, C N. Eter, C. Jochmann, H. Schilling, P. Wiedemann, H. Sachs, Z. Hasanbasic, Wachtlin J. PERSEUS 12 month analysis: A Prospective Non-interventional Study to Assess the Effectiveness of Intravitreal Afl ibercept in Routine Clinical Practice in Patients with Wet Age-related Macular Degeneration. 16th EURETINA Congress - Copenhagen, 2016.

8. Oubraham-Mebroukine H, Faure C, Cosccas F et al. Real Life Use of Intravitreal Aflibercept In France : Observational study in Wet AMD : the RAINBOW study. Association for Research in Vision and Ophthalmology (AVRO), poster 524-A0161.2016.

9. Mori R, Ohji M, Takahashi K, Ishibashi T, Migita H, Sakaguchi T, et al. Intravitreal aflibercept in wet age-related macular degeneration patients from Japan: 6-month outcomes of J-PMS. Association for Research in Vision and Ophthalmology (AVRO), poster 536. 2016.

10. Epstein D, Amrén U. Near vision outcome in patients with age-related macular degeneration treated with aflibercept. Retina. 2016; 36(9): 1773-1777, doi: 10.1097/IAE.0000000000000978, indexed in Pubmed: 26866528.

11. Lee AY, Lee CS, Egan CA, et al. UK AMD/DR EMR REPORT IX: comparative effectiveness of predominantly as needed (PRN) ranibizumab versus continuous aflibercept in UK clinical practice. $\mathrm{Br} \mathrm{J}$ Ophthalmol. 2017 [Epub ahead of print], doi: 10.1136/bjophthalmol-2016-309818, indexed in Pubmed: 28478396.

12. Eleftheriadou M, Vazquez-Alfageme $\mathrm{C}$, Citu CM, et al. Long-term outcomes of aflibercept treatment for neovascular age-related macular degeneration in a clinical setting. Am J Ophthalmol. 2017; 174: 160-168, doi: 10.1016/j.ajo.2016.09.038, indexed in Pubmed: 27746298.

13. Barthelmes D, Nguyen V, Daien V, et al. Fight Retinal Blindness Study Group. Two year outcomes of "treat and extend" intravitreal therapy using aflibercept preferentially for neovascular age-related macular degeneration. Retina. 2017 [Epub ahead of print], doi: 10.1097/ IAE.0000000000001496, indexed in Pubmed: 28145976.

14. Talks JS, Lotery AJ, Ghanchi F, et al. United Kingdom Aflibercept Users Group. First-year visual acuity outcomes of providing aflibercept according to the VIEW study protocol for age-related macular degeneration. Ophthalmology. 2016; 123(2): 337-343, doi: 10.1016/j. ophtha.2015.09.039, indexed in Pubmed: 26578446.

15. Almuhtaseb H, Johnston RL, Talks JS, et al. Second-year visual acuity outcomes of nAMD patients treated with aflibercept: data analysis from the UK Aflibercept Users Group. Eye (Lond). 2017 [Epub ahead of print], doi: 10.1038/eye.2017.108, indexed in Pubmed: 28622328.

16. Kaiser $P$, Singer $M$, Tolentino $M$, et al. Long-term safety and visual outcome of intravitreal aflibercept in neovascular age-related macular degeneration. Ophthalmology Retina. 2017; 1(4): 304-313, doi: 10.1016/j.oret.2017.01.004.

17. DeCroos FC, Reed D, Adam MK, et al. Treat-and-Extend Therapy Using Aflibercept for Neovascular Age-related Macular Degeneration: A Prospective Clinical Trial. Am J Ophthalmol. 2017; 180: 142-150, doi: 10.1016/j.ajo.2017.06.002, indexed in Pubmed: 28624325.

18. Holz FG, Bandello F, Gillies M, et al. LUMINOUS Steering Committee. Safety of ranibizumab in routine clinical practice: 1-year retrospective pooled analysis of four European neovascular AMD registries within the LUMINOUS programme. Br J Ophthalmol. 2013; 97(9): 1161-1167, doi: 10.1136/bjophthalmol-2013-303232, indexed in Pubmed: 23850682.

19. Wolf $A$, Kampik A. Efficacy of treatment with ranibizumab in patients with wet age-related macular degeneration in routine clinical care: data from the COMPASS health services research. Graefes Arch Clin Exp Ophthalmol. 2014; 252(4): 647-655, doi: 10.1007/s00417-0132562-6, indexed in Pubmed: 24424409.

20. Writing Committee for the UK Age-Related Macular Degeneration EMR Users Group. Yang Y, Downey L, Mehta H, et al. Resource use and real-world outcomes for ranibizumab treat and extend for neovascular age-related macular degeneration in the uk: interim results from TERRA. Ophthalmol Ther. 2017; 6(1): 175-186, doi: 10.1007/ s40123-017-0091-9, indexed in Pubmed: 28508241.

21. Silva R, Goncalves $C$, Meireles A, et al. A Retrospective Analysis of the Real-Life Utilization of Ranibizumab in Patients with Wet Age-Related Macular Degeneration from Portugal. Acta Med Port. 2017; 30(6): 449-456, indexed in Pubmed: 28898611.

22. Writing Committe for the UK Age-Related Macular Degeneration EMR Users Group. The Neovascular Age-Related Macular Degeneration Database: Multicenter Study of 92976 Ranibizumab Injections. Ophthalmology. 2014; 121(5): 1092-1101, doi: 10.1016/j. ophtha.2013.11.031.

23. Berg K, Pedersen TR, Sandvik L, et al. Comparison of ranibizumab and bevacizumab for neovascular age-related macular degeneration according to LUCAS treat-and-extend protocol. Ophthalmology. 2015; 122(1): 146-152, doi: 10.1016/j.ophtha.2014.07.041, indexed in Pubmed: 25227499.

24. Wykoff C, Ou W, Brown D, et al. Randomized trial of treat-and-extend versus monthly dosing for neovascular age-related macular degene- 
ration. Ophthalmology Retina. 2017; 1(4): 314-321, doi: 10.1016/j. oret.2016.12.004.

25. Chen YN, Powell AM, Mao A, et al. Retrospective review of lucentis "treat and extend" patterns and outcomes in age-related macular degeneration. Retina. 2016; 36(2): 272-278, doi: 10.1097/ IAE.0000000000000691, indexed in Pubmed: 26200511.

26. Ho AC, Busbee BG, Regillo CD, et al. HARBOR Study Group. Twenty -four-month efficacy and safety of $0.5 \mathrm{mg}$ or $2.0 \mathrm{mg}$ ranibizumab in patients with subfoveal neovascular age-related macular degeneration. Ophthalmology. 2014; 121(11): 2181-2192, doi: 10.1016/j. ophtha.2014.05.009, indexed in Pubmed: 25015215.

27. Lalwani $G A$, Rosenfeld PJ, Fung $A E$, et al. A variable-dosing regimen with intravitreal ranibizumab for neovascular age-related macular degeneration: year 2 of the PrONTO Study. Am J Ophthalmol. 2009; 148(1): 43-58.e1, doi: 10.1016/j.ajo.2009.01.024, indexed in Pubmed: 19376495.

28. Singer MA, Awh CC, Sadda S, et al. HORIZON: an open-label extension trial of ranibizumab for choroidal neovascularization secondary to age-related macular degeneration. Ophthalmology. 2012; 119(6): 1175-1183, doi: 10.1016/..ophtha.2011.12.016, indexed in Pubmed: 22306121.

29. Holz FG, Korobelnik JF, Lanzetta P, et al. The effects of a flexible visual acuity-driven ranibizumab treatment regimen in age-related macular degeneration: outcomes of a drug and disease model. Invest Ophthalmol Vis Sci. 2010; 51(1): 405-412, doi: 10.1167/iovs.09-3813, indexed in Pubmed: 19661237.

30. Schmidt-Erfurth U, Waldstein S. A paradigm shift in imaging biomarkers in neovascular age-related macular degeneration. Progress in Retinal and Eye Research. 2016; 50: 1-24, doi: 10.1016/j.preteyeres.2015.07.007.

31. Chong V, Chong V. Ranibizumab for the treatment of wet AMD: a summary of real-world studies. Eye (Lond). 2016; 30(2): 270-286, doi: 10.1038/eye.2015.217, indexed in Pubmed: 26634711.

32. Holz FG, Tadayoni R, Beatty $S$, et al. Key drivers of visual acuity gains in neovascular age-related macular degeneration in real life: findings from the AURA study. Br J Ophthalmol. 2016; 100(12): 1623-1628, doi: 10.1136/bjophthalmol-2015-308166, indexed in Pubmed: 27030279.

33. Huang D, Jia Y, Rispoli M, et al. Optical coherence tomography angiography of time course of choroidal neovascularization in response to anti-angiogenic treatment. Retina. 2015; 35(11): 2260-2264, doi: 10.1097/iae.0000000000000846.

34. Fung AE, Lalwani GA, Rosenfeld PJ, et al. An optical coherence tomography-guided, variable dosing regimen with intravitreal ranibizumab (Lucentis) for neovascular age-related macular degeneration. Am J Ophthalmol. 2007; 143(4): 566-583, doi: 10.1016/j.ajo.2007.01.028, indexed in Pubmed: 17386270.

35. Waldstein SM, Wright J, Warburton J, et al. Predictive Value of Retinal Morphology for Visual Acuity Outcomes of Different Ranibizumab Treatment Regimens for Neovascular AMD. Ophthalmology. 2016; 123(1): 60-69, doi: 10.1016/j.ophtha.2015.09.013, indexed in Pubmed: 26481821.

36. Waldstein SM, Philip AM, Leitner R, et al. Correlation of 3-Dimensionally Quantified Intraretinal and Subretinal Fluid With Visual Acuity in
Neovascular Age-Related Macular Degeneration. JAMA Ophthalmol. 2016; 134(2): 182-190, doi: 10.1001/jamaophthalmol.2015.4948, indexed in Pubmed: 26661463. pto.com.pl/storage/guidelines/3/ adfcdea8665bb0bf6947556cefe64ffe.pdf.

37. Pelosini L, Hull CC, Boyce JF, et al. Optical coherence tomography may be used to predict visual acuity in patients with macular edema. Invest Ophthalmol Vis Sci. 2011; 52(5): 2741-2748, doi: 10.1167/ iovs.09-4493, indexed in Pubmed: 20538987.

38. Jaffe GJ, Martin DF, Toth CA, et al. Comparison of Age-related Macular Degeneration Treatments Trials Research Group. Macular morphology and visual acuity in the comparison of age-related macular degeneration treatments trials. Ophthalmology. 2013; 120(9): 1860-1870, doi: 10.1016/j.ophtha.2013.01.073, indexed in Pubmed: 23642377.

39. Dirani A, Ambresin A, Marchionno L, et al. Factors Influencing the Treatment Response of Pigment Epithelium Detachment in Age-Related Macular Degeneration. Am J Ophthalmol. 2015; 160(4): 732-8.e2, doi: 10.1016/j.ajo.2015.06.025, indexed in Pubmed: 26144701.

40. Gianniou C, Dirani A, Jang L, et al. Refractory intraretinal or subretinal fluid in neovascular age-related macular degeneration treated with intravitreal ranizubimab: Functional and structural outcome. Retina. 2015; 35(6): 1195-1201, doi: 10.1097/IAE.00000000000000465, indexed in Pubmed: 25650710.

41. Pokroy R, Mimouni M, Barayev E, et al. Prognostic value of subretinal hyperreflective material in neovascular age-related macular degeneration treated with bevacizumab. Retina. 2017 [Epub ahead of print], doi: 10.1097/IAE.0000000000001748, indexed in Pubmed: 28654630.

42. Grunwald JE, Pistilli M, Daniel E, et al. Comparison of Age-Related Macular Degeneration Treatments Trials Research Group. Incidence and growth of geographic atrophy during 5 years of comparison of age-related macular degeneration treatments trials. Ophthalmology. 2017; 124(1): 97-104, doi: 10.1016/j.ophtha.2016.09.012, indexed in Pubmed: 28079023.

43. Grunwald J, Pistilli M, Ying G, et al. Growth of geographic atrophy in the comparison of age-related macular degeneration treatments trials. Ophthalmology. 2015; 122(4): 809-816, doi: 10.1016/j. ophtha.2014.11.007.

44. Ying G, Kim BJ, Maguire MG, et al. CATT Research Group. Sustained visual acuity loss in the comparison of age-related macular degeneration treatments trials. JAMA Ophthalmol. 2014; 132(8): 915-921, doi: 10.1001/jamaophthalmol.2014.1019, indexed in Pubmed: 24875610.

45. Grunwald JE, Daniel E, Huang J, et al. CATT Research Group. Risk of geographic atrophy in the comparison of age-related macular degeneration treatments trials. Ophthalmology. 2014; 121(1): 150-161, doi: 10.1016/j.ophtha.2013.08.015, indexed in Pubmed: 24084496.

46. Coscas F, Coscas G, Lupidi M, et al. Restoration of outer retinal layers after aflibercept therapy in exudative AMD: Prognostic value. Invest Ophthalmol Vis Sci. 2015; 56(6): 4129-4134, doi: 10.1167/iovs.1516735, indexed in Pubmed: 26114491.

47. Schmidt-Erfurth U, Bogunovic H, Sadeghipour A, et al. Machine learning to analyze the prognostic value of current imaging biomarkers in neovascular age-related macular degeneration. Ophthalmology Retina. 2017, doi: 10.1016/j.oret.2017.03.015. 